\title{
PENYULUHAN PEMBUATAN KAMABOKO DI UMKM TANGSEL BERKIBAR TANGERANG SELATAN, BANTEN
}

\author{
Wenny Silvia Loren Br Sinaga ${ }^{1}$, Tagor M. Siregar ${ }^{1}$, Nuri Arum Anugrahati ${ }^{1}$, Melanie \\ Cornelia $^{1}$, Intan Cidarbulan Matita ${ }^{1}$ \\ ${ }^{1}$ Universitas Pelita Harapan, Tangerang, Banten
}

Email: wenny.sinaga@uph.edu, tagor.siregar@uph.edu, nuri.anugrahati@uph.edu, melanie.cornelia@uph.edu, intan.matita@uph.edu.

\begin{abstract}
Abstrak
Kondisi pandemi COVID-19 telah mengakibatkan jumlah pengangguran semakin meningkat. Hal ini mendorong berbagai usaha untuk memperluas lapangan usaha. Salah satu usaha memperluas lapangan usaha adalah memperdayakan masyarakat melalui penguatan usaha kecil dan menengah. Komunitas Usaha Mikro Kecil Menengah (UMKM) Berkibar merupakan salah satu UMKM di wilayah Tangerang Selatan. Namun usaha makanannya belum dikembangkan ke bidang usaha produk olahan perikanan. Berdasarkan hal tersebut, maka Program Studi Teknologi Pangan Universitas Pelita Harapan (UPH) melakukan kegiatan Pengabdian kepada Masyarakat (PkM) dalam bentuk penyuluhan. Tujuan PkM adalah untuk memberikan informasi tentang bahan dan cara pembuatan Kamaboko. Metode PkM adalah penyuluhan secara daring yang meliputi pemaparan materi, penayangan video, dan tanya jawab. Hasil dari penyuluhan ini para pelaku UMKM di Tangsel Berkibar mendapatkan informasi baru mengenai olahan perikanan dan antusiasme dari peserta untuk keberlanjutan dari PkM ini.
\end{abstract}

Kata Kunci: Kamaboko, pandemik, penyuluhan, UMKM

\section{PENDAHULUAN}

Pandemi COVID-19 yang terjadi sejak Maret 2020 di Indonesia telah memberi dampak yang serius bagi tatanan kesehatan, perekonomian, dan sosial masyarakat. Salah satu dampak pandemi COVID-19 adalah semakin banyaknya masyarakat yang mengalami Pemutusan Hubungan Kerja (PHK) dengan alasan force majeure atau mengalami kerugian. Hal ini mengakibatkan naiknya angka pengangguran di Indonesia. Menurut data statistik, Tingkat Pengangguran Terbuka (TPT) di bulan
Agustus 2020 sebesar 7,07\%, meningkat 1,84\% dibandingkan dengan Agustus 2019 (BPS,2020). Oleh karena itu, diperlukan berbagai upaya untuk mengurangi angka pengangguran di Indonesia dengan membuka lapangan usaha di bidang makanan dan minuman.

Usaha di bidang makanan selama masa pandemi COVID-19 sangat diminati. Hal ini disebabkan makanan merupakan kebutuhan pokok masyarakat dan tergolong praktis dalam penyediannya. Usaha di bidang makanan dapat dikelompokkan menjadi 3 kelompok utama menurut 
jenis bahan pangannya,yaitu bahan pangan segar, kering, dan olahan. Bahan pangan olahan meliputi bahan pangan yang setengah jadi atau yang sudah diolah. Bahan pangan setengah jadi merupakan bahan pangan mentah yang telah mengalami pengolahan dengan cara pengawetan. Keuntungan olahan pangan setengah jadi adalah memiliki umur simpan yang lebih lama, menjadi bahan baku yang fleksibel untuk industri pengolahan lanjutan, mengurangi biaya dan menghemat ruangan dalam penyimpanan.

Salah satu bahan pangan setengah jadi dari hasil perikanan adalah Kamaboko. Kamaboko merupakan bahan pangan yang berasal dari gel ikan, bersifat kenyal dan elastis, serta pada umumnya telah diberi penambahan garam dan tepung (Rahayu, 2020). Gel ikan yang dibuat menjadi Kamaboko berasal dari lumatan daging ikan yang memiliki karakteristik gel oleh adanya protein miofibril ikan, yaitu aktin dan miosin. Gel yang terbentuk terjadi saat pencampuran garam dalam lumatan daging. Gel tidak hanya terbentuk melalui hidrasi molekul protein, tetapi juga pembentukan struktur jaringan oleh ikatan hidrogen, ikatan hidrofobik dan molekul protein myofibril (Nakazawa dan Okazaki, 2020). Kualitas gel Surimi selama pembekuan dapat dipertahankan dengan menambahkan cryoprotectant seperti sukrosa, sorbitol, protein putih telur. Penambahan cryoprotectant dapat mencegah denaturasi protein selama pembekuan (Laksono et al., 2020 dan Walayat et al., 2020). Kamaboko dapat dibuat dari berbagai jenis ikan, baik ikan air laut maupun ikan air tawar. Beberapa jenis ikan yang telah dibuat menjadi Kamaboko yaitu ikan tenggiri, mayong, nila, dan cumi-cumi (Hansnelly et al., 2020). Tepung yang dapat ditambahkan berupa tepung terigu, tepung tapioka, atau tepung maizena. Produk analog Kamaboko di Indonesia berupa bakso ikan dan pempek (Azka dan Mujiyanti, 2020).

Program Studi Teknologi Pangan Universitas Pelita Harapan (UPH) sebagai salah satu pelaksana pendidikan tinggi di bidang teknologi pangan memiliki salah satu misi yaitu mewujudkan pembelajaran di bidang ilmu dan teknologi pangan yang sesuai dengan kebutuhan masyarakat. Berdasarkan misi tersebut, maka Program Studi Teknologi Pangan UPH akan melaksanakan Pengabdian kepada Masyarakat (PkM) melalui kegiatan webinar yang berjudul "Penyuluhan Pembuatan Kamaboko di UMKM Tangsel Berkibar, Tangerang Selatan-Banten". Penyuluhan ini penting dilakukan mengingat semakin tingginya angka pengangguran di Indonesia dan masyarakat membutuhkan lapangan usaha yang praktis di bidang makanan. Kegiatan PkM Program Studi Teknologi Pangan bertujuan untuk: 1) Memberikan informasi bahan untuk membuat Kamaboko, 2) Memberikan informasi tentang cara pembuatan Kamaboko, 3) Memberikan informasi daya terima Kamaboko. Masalah yang akan diselesaikan melalui kegiatan PkM ini adalah: 1). Belum banyak informasi yang diterima oleh UMKM Tangsel Berkibar, Tangerang SelatanBanten tentang bahan untuk membuat Kamaboko, dan 2). Belum banyak informasi yang diterima oleh UMKM Tangsel Berkibar, Tangerang SelatanBanten tentang cara pembuatan kamboko.

\section{METODE}

Metode pelatihan yang digunakan terlebih dahulu melalui pendekatan dengan ketua UMKM Tangsel Berkibar. Selama ini mereka menggunakan ikan untuk diolah dan sangat tertarik untuk meningkatkan nilai jual ikan. Salah satu kegiatan UMKM adalah memproduksi makanan khas palembang yaitu pempek menggunakan ikan tenggiri. Pembahasan mengenai kebutuhan dan disesuaikan dengan permintaan anggota UMKM melalui daring.

Tim PkM UPH melakukan formulasi untuk membuat Kamaboko menggunakan ikan tenggiri. Setelah formulasi didapatkan dilakukan pengambilan video. Kamaboko yang sudah jadi disimpan dalam suhu freezer untuk melihat apakah ada perubahan selama penyimpanan. Kemudian untuk persiapan terakhir dilakukan pembuatan slide untuk pemaparan di hari yang telah ditentukan. Kegiatan ini dilakukan secara daring melalui aplikasi "Zoom meeting". Gambar 1 merupakan flyer kegiatan PkM yang dikirimkan ke seluruh anggota UMKM sebagai bentuk undangan untuk menghadiri kegiatan PkM bersama Teknologi Pangan UPH. Untuk menilai keberhasilan dari PkM ini, kami menyediakan kuisioner untuk diisi oleh 
peserta. Adapun kuisioner yang dibagikan dalam bentuk Google Form sehingga dengan mudah diakses dan dapat hasilnya.

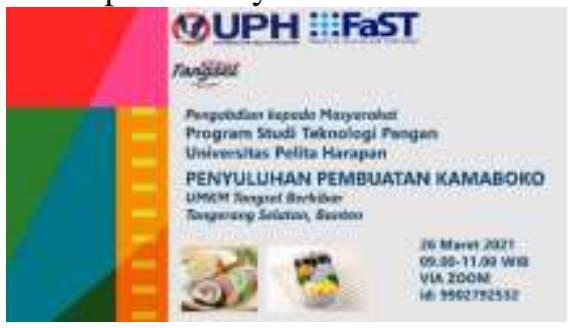

Gambar 1. Flyer kegiatan PkM untuk UMKM Tangsel Berkibar

HASIL DAN PEMBAHASAN

\section{UMKM Tangsel Berkibar}

UMKM Tangsel Berkibar merupakan komunitas dari pelaku IKM dan UKM yang ada di Tangsel. Tangsel Berkibar memiliki komunitas dengan hampir 900 orang. Tujuan awal berorganisasi untuk membantu teman-teman yang ingin punya legalitas akan produk yang dimiliki, mulai dari merek, PIRT, BPOM, halal dan lainnya. Sejak tahun 2019 Tangsel Berkibar sudah menjadi koperasi dan diharapkan dapat berkontribusi dalam perdanganan hasil UKM dari anggotanya. Sebagian besar anggota dari UMKM Tangsel Berkibar sudah memiliki PIRT, SBU, dan HAKI. Hal ini menunjukkan keseriusan dalam bidang usaha mereka. Gambar 2 merupakan peta lokasi dari Tangsel Berkibar.

UPH hadir untuk membantu memberikan ide-ide bisnis lain yang mungkin bisa dikerjakan oleh para pelaku UMKM. Diawal komunikasi dengan ketua UMKM Tangsel Berkibar melalui pesan elektronik (whatsapps) disampaikan bahwa mereka menginginkan untuk diberikan pelatihan yang bshan dasarnya ikan supaya bisa diolah dan diperpanjang masa simpannya, sehingga dapat dipasarkan lebih luas dibandingkan dengan ikan segar.

Upaya yang dapat dilakukan dalam mempertahankan mutu dan meningkatkan nilai tambah dari bahan yang berasal dari ikan seperti ikan tenggiri dengan membuat menjadi kamboko yang dapat disimpan lebih lama dibandingkan dengan ikan segar. Karakteristik Kamaboko harus disesuaikan dengan kandungan daging merah dan daging putih pada ikan. Minimnya pengetahuan tentang pengolahan ikan akan menyebabkan kegagalan dalam pembuatan Kamaboko. Makanan beku dapat memperpanjang umur simpan sehingga memudahkan untuk distribusi.

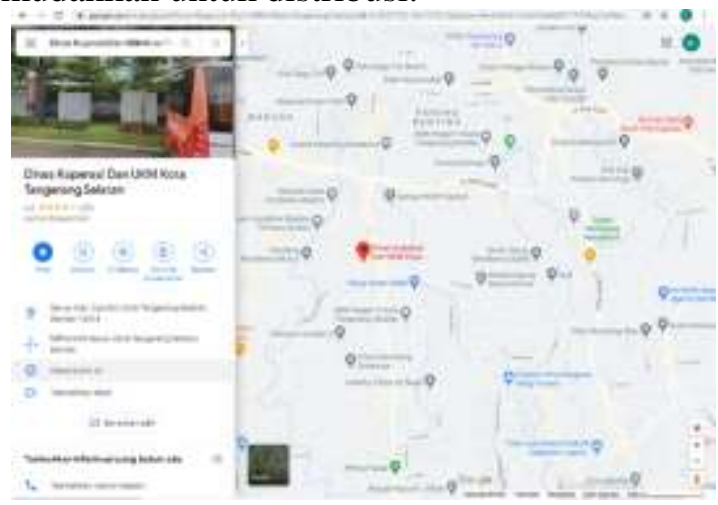

Gambar 2. Peta lokasi mitra sasaran

\section{Formulasi Pembuatan Kamaboko}

Bahan yang dapat digunakan dalam pembuatan Kamaboko adalah ikan Pollock, ikan Tenggiri, ikan Nila, ikan Lele, daging sapi dan ayam. Dimana semua bahan ini memiliki karakteristik gel elastik. Namun yang dipilih adalah ikan tenggiri dan diupayakan bagian daging putihnya saja. Karna daging merah memiliki banyak lemak yang kemungkinan akan mengganggu elastisitas dari Kamaboko. Daging ikan yang dipisahkan kemudian dicuci menggunakan air es. Tujuannya adalah untuk memisahkan protein ikan dari lemaknya. Hal ini dilakukan sebanyak 3 sampai 5 kali guna mendapatkan hasil yang baik. Ketika akan diambil, kita gunakan kain saring agar daging ikan didapatkan maksimal.

Pasta ikan yang sudah kita dapatkan dinamakan Surimi. Surimi kemudian ditambahkan sodium tripoliposphat dan tepung tapioka. Sodium tripoliposfat digunakan sebagai bahan pengikat, penyerap dan penahan air sehingga adonan yang dihasilkan tidak terlalu keras. Tepung tapioka juga ditambahkan agar tekstur dari Kamaboko menjadi kenyal. Surimi yang dibuat kemudian dipanaskan 2 kali, pertama disuhu $50^{\circ} \mathrm{C}$ dan di suhu $100^{\circ} \mathrm{C}$. Pemanasan di suhu $50^{\circ} \mathrm{C}$ dilakukan agar adonan tidak pecah. Suhu $100^{\circ} \mathrm{C}$ untuk proses pematangan. STPP yang diberikan sekitar $0.3 \%$ dari total pasta 
Surimi, garam 1,5\% dari total berat pasta Surimi, tapioka $10 \%$ dari pasta Surimi.

Masa simpan Kamaboko dapat mencapai 3 bulan jika disimpan di suhu dibawh $0^{\circ} \mathrm{C}$. Keadaan yang dimaksud adalah kondisi dimana Kamaboko masih aman untuk dikonsumsi tanpa ada perubahan rasa, aroma dan tekstur secara signifikan. Jika terlalu lama khawatir tekstrur, rasa dan aroma sudah berubah. Kamaboko mirip dengan adonan dasar makanan khas Palembang yaitu Pempek. Bedanya hanya pada bumbu dan juga metode perebusannya.

\section{Pelaksanaan Kegiatan PkM}

Kegiatan Pengabdian kepada Masyarakat (PkM) Program Studi Teknologi Pangan dengan UMKM Tangsel Berkibar dilaksanakan secara virtual (webinar), oleh karena adanya kebijakan PPKM (Pemberlakuan Pembatasan Kegiatan Masyarakat) di wilayah Tangerang Raya akibat adanya wabah virus Covid 19. Kegiatan PkM ini dilaksanakan pada tanggal 26 Maret 2021 pada pukul 09.00 - 12.00 WIB. Kegiatan ini diawali dengan acara pembukaan yang meliputi doa pembuka dan sambutan oleh ketua UMKM Tangsel Berkibar (Bapak Tasrudin) (Gambar 3), dilanjutkan dengan sambutan dan perkenalan anggota Tim PkM oleh Ketua Tim PKM (Wenny Silvia Loren $\mathrm{Br}$ Sinaga, M.Si.). Kegiatan ini diikuti oleh 60 orang peserta yang merupakan anggota dari UMKM Tangsel Berkibar, Tangerang Selatan.

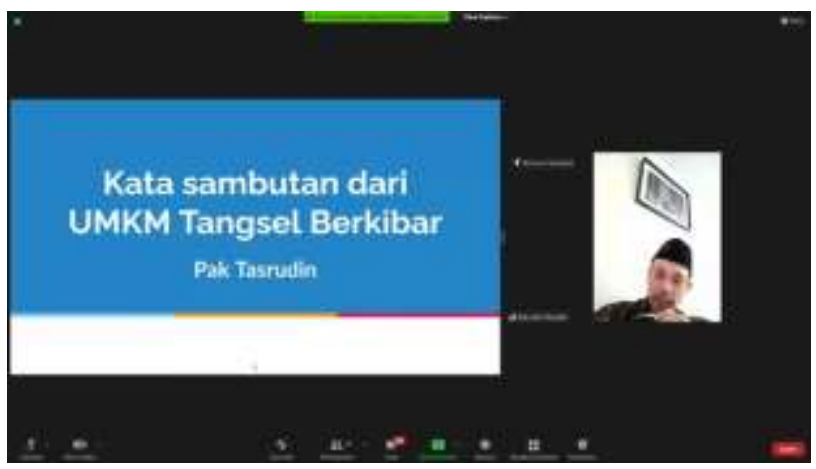

Gambar 3. Kata Sambutan dari ketua UMKM Tangsel Berkibar (Bapak Tazrudin)

Kegiatan PkM berupa penyuluhan tentang pembuatan Kamaboko 2 sesi, yaitu sesi pertama berupa presentasi mengenai Kamaboko, dan pemutaran video pembuatan Kamaboko (Gambar 4). Sesi kedua berupa diskusi tentang bahan-bahan yang berpotensi untuk dikembangkan sebagai produk Kamaboko. Seluruh informasi ini dirangkum dalam bentuk slide presentasi (ms-powerpoint) yang dipaparkan dan dijelaskan pada saat pelaksanaan kegiatan PkM melalui platform "zoom meeting".
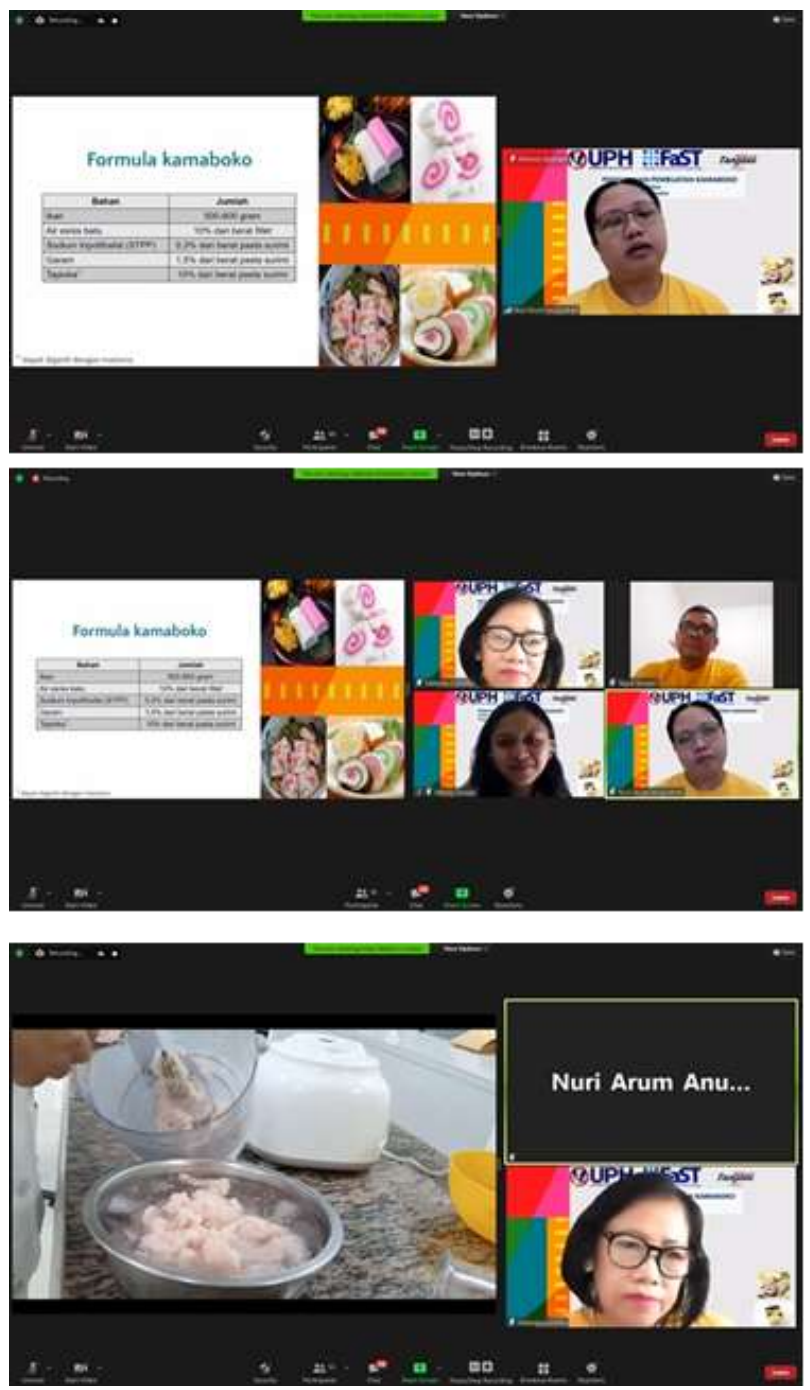

Gambar 4. Situasi pemaparan presentasi

Setelah pemaparan dan penjelasan materi selesai dilakukan, kegiatan diskusi dan tanya jawab langsung dilakukan untuk mengetahui respon dan memfasilitasi berbagai pertanyaan dari peserta mengenai Kamaboko dan hal-hal apa saja yang mungkin memengaruhi proses pembuatan dari 
Kamaboko (Gambar 5). Beberapa peserta secara langsung menyampaikan pendapat yang positif mengenai pelaksanaan $\mathrm{PkM}$ ini diakhir diskusi. Untuk merangkum respon yang diperoleh dari kegiatan PkM ini, maka seluruh peserta juga diminta kesediaannya untuk mengisi daftar hadir dan kuesioner yang telah disiapkan.
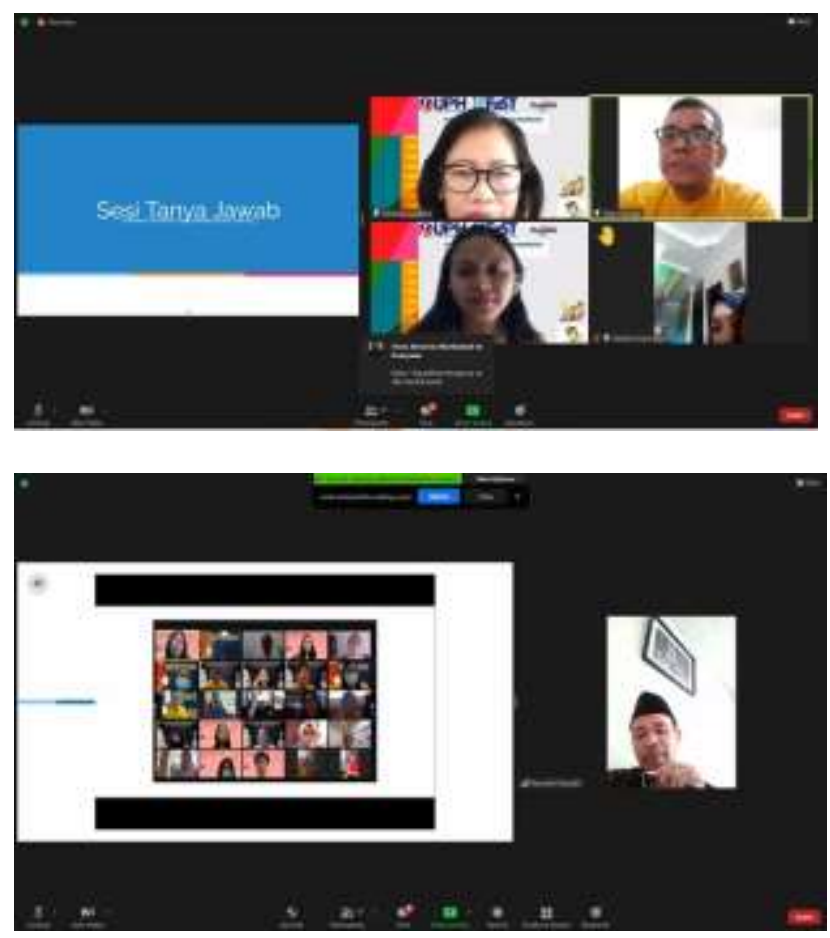

Gambar 5. Sesi tanya jawab

Penyerahan souvenir secara simbolis kepada UMKM Tangsel Berkibar dilakukan setelah mengisi kuesioner. Acara serah terima ini disertai dengan penandatanganan berita acara pelaksanaan kegiatan PkM (yang sudah dikirim terlebih dahulu ke UMKM Tangsel Berkibar) oleh UMKM Tangsel Berkibar (Bapak Tazrudin) dan Teknologi Pangan UPH (Wenny Silvia Loren Br Sinaga M.Si.).

Acara kemudian ditutup dengan ucapan terima kasih oleh Ketua UMKM Tangsel Berkibar (Bapak Tazrudin) atas terselenggaranya kegiatan PkM ini dengan sangat baik berkat kerjasama Tim PkM Program Studi Teknologi Pangan UPH dengan pihak UMKM Tangsel Berkibar. Setelah itu, keseluruhan rangkaian acara ditutup dengan doa yang dipimpin oleh Ibu Intan dari Tim PkM UPH. Kegiatan PkM ini dapat terselenggara dengan baik berkat antusiasme dan respon positif dari para peserta selama kegiatan PkM ini berlangsung.

\section{Hasil Kegiatan}

Peserta PKM memberikan respon positif terhadap pelaksanaan kegiatan PkM di UMKM Tangsel Berkibar. Hal ini terlihat dari respon peserta, yaitu sebanyak $96,6 \%$ peserta menyatakan bahwa kegiatan ini dapat diikuti dengan baik dan sebanyak $100 \%$ peserta merasa bahwa topik yang dibawakan bermanfaat. Hasil kuesioner ini juga menunjukkan bahwa sebanyak $69,66 \%$ peserta termotivasi untuk menerapkan pengetahuan yang diperoleh pada penyuluhan dalam rutinitas harian dan sebanyak $67,8 \%$ peserta berkeinginan meneruskan informasi yang diperoleh pada penyuluhan kepada orang lain. Selain itu para peserta penyuluhan memberikan beberapa masukan dan saran seperti pelaksanaan PkM dilakukan secara rutin, penambahan waktu/durasi pelaksanaan penyuluhan, topik penyuluhan keamanan pangan dan harapan diadakan dalam bentuk offline.

\section{KESIMPULAN}

Kegiatan PKM "Penyuluhan Pembuatan Kamaboko di UMKM Tangsel Berkibar, Tangerang Selatan, Banten." telah dilaksanakan dengan baik sesuai dengan perencanaan yang telah dilakukan. Kegiatan ini dilakukan pada tanggal 26 Maret 2021 dan diikuti oleh 53 orang peserta dan 7 orang tim penyuluh, yang terdiri dari 5 orang dosen dan 2 orang mahasiswa Program Studi Teknologi Pangan. Bentuk kegiatan PkM ini berupa presentasi materi pembuatan Kamaboko dan diskusi terkait materi yang disampaikan dengan peserta.

Kegiatan PkM ini dapat terus dilakukan oleh Program Studi Teknologi Pangan UPH di UMKM Tangsel Berkibar mengingat respon positif yang disampaikan oleh para peserta kegiatan, yaitu bahwa topik PkM yang dibawakan sangat bermanfaat dan dapat diikuti dengan baik oleh para peserta. Para peserta juga menginginkan adanya kegiatan penyuluhan atau pelatihan yang dilaksanakan secara berkala dengan topik yang 
disesuaikan dengan kebutuhan dan potensi sumber daya yang ada.

\section{UCAPAN TERIMAKASIH}

Ucapan terimakasih disampaikan kepada UMKM Tangsel Berkibar dan juga LPPM UPH, serta Program Studi Teknologi Pangan UPH yang telah memberikan kontribusi dalam pelaksanaan kegiatan.

\section{REFERENSI}

Azka, A. dan Mujiyanti, A. (2020). Pengaruh Penambahan Sodium Tripoliphosphat terhadap Tingkat Kesukaan Kamaboko Ikan Malong (Muraenesox cinerus), Authentic Research of Global Fisheries Application Journal, 1(2):129136.

BPS, (2020). Badan Pusat Statistik, Jakarta, bps.go.id

https://www.bps.go.id/pressrelease/2020/11/05/167 3/agustus-2020--tingkat-pengangguran-terbuka--tpt-sebesar-7-07-persen.html

Hasnelly, Achyadi, NS, dan Fatimah, FN. (2020). Karakteristik Kamaboko dengan Susbtitusi Tepung Ubi Jalar dan Tinta Cumi-cumi (Loligo sp.),
Jurnal Pengolahan Hasil Perikanan Indonesia, 23(1):333-341.

Laksono, UT, Suprihatin, Nurhayadi, T, Romli, M. (2019). Peningkatan Kualitas Tekstur Surimi Ikan Malong dengan Sodium Tripolifosfat dan Aktivator Transglutaminase, Jurnal Hasil Perikanan Hasil Perikanan Indonesia, 22(2):198208.

Nakazawa, N. dan Okazaki, E. (2020), Recent Research on Factors Influencing the Quality of Frozen Seafood. Fisheries Science, 86:231-244.

Rahayu, WE. (2020). Daya Terima dan Analisis Ekonomi Kamaboko Jenis Ikan Laut dalam Meningkatkan Nilai Tambah Produksi Ikan Subang, Jurnal Ilmiah Ilmu dan Teknologi Rekayasa, 3(1):18.

Walayat, N, Xiong, H, Xiong, Z, Moreno, HM, Nawaz, A, Niaz, N, dan Randhawa, MA, (2020). Role of Cryoprotectants in Surimi and Factors Affecting Surimi Gel Properties: A Review, Food Reviews International, https://doi.org/10.1080/87559129.2020.1768403. 